\title{
WYBRANE ASPEKTY PROBLEMATYKI WSPÓŁTWÓRCZOŚCI UTWORÓW NAUKOWYCH
}

\section{Uwagi ogólne}

Zagadnienie szeroko rozumianej współpracy naukowej stało się przedmiotem zainteresowania przedstawicieli doktryny już w latach sześćdziesiątych $\mathrm{XX} \mathrm{w.}{ }^{2} \mathrm{Wy}-$ nikało to w szczególności z faktu znaczącego wzrostu powstawania publikacji naukowych, będących rezultatem pracy twórczej dwóch i więcej autorów. Co istotne, autorzy przedmiotowych utworów pochodzą coraz częściej z różnych ośrodków naukowych, zarówno krajowych, jak i zagranicznych. Przykładowo, w 2007 r. 21,9\% artykułów z zakresu nauk ścisłych było efektem współpracy międzynarodowej, co oznacza trzykrotny wzrost w porównaniu do roku 1985. ${ }^{3}$ Jakkolwiek nie budzi przy tym wątpliwości fakt, że współpraca naukowa i współtwórczość utworów naukowych jest w głównej mierze domeną nauk ścisłych, to wiele ustaleń w tym zakresie znajduje także zastosowanie do nauk społecznych. ${ }^{4}$

Natomiast biorąc pod uwagę szeroko rozumianą współpracę, współdziałanie i partnerstwo międzynarodowe w dziedzinie nauki jako takiej, pomiędzy $1990 \mathrm{r}$. a 2005 liczba utworów współautorskich wzrosła trzykrotnie - w 1990 r. było 50.000 artykułów współautorskich, natomiast liczba ta wzrosła do ok. $150.000 \mathrm{w}$ roku 2005. Jednocześnie należy odnotować znaczący wzrost publikacji międzynarodowych, gdzie w 1990 r. przestawiono 150.000 prac międzynarodowych, a w 2005 roku 600.000 , co oznacza czterokrotny wzrost. ${ }^{5}$

1 Doktor nauk prawnych, Katedra Prawa Własności Intelektualnej Wydziału Prawa Uniwersytetu w Białymstoku.

2 W. Glänzel, A. Schubert, Analysing scientific networks through co-authorship, (w:) H.F. Moed, W. Glänzel, U. Schmoch (red.), Handbook of Quantitative Science and Technology Research, 2005, s. 257.

3 OECD Science Technology and Industry Scoreboard 2009, s. 114.

4 Por. J.W. Endersby, Collaborative Research in the Social Science: Multiple Authorship and Publication Credit, "Social Science Quarterly" 1996, vol. 77, nr 2, s. 375 i n.

5 J.A. Teixeira da Silva, The ethics of collaborative authorship, „European Molecular Biology Organization Report” vol. 12, nr 9 (2011), s. 889 . 
$\mathrm{Na}$ gruncie literatury przedmiotu podejmowano próby określenia czynników warunkujących powstawanie wspólnych prac naukowych i podejmowanie współpracy naukowej. Wspólne dla przedstawicieli doktryny jest twierdzenie, że problem współautorstwa i współpracy naukowej jest zagadnieniem złożonym i determinowanym przez szereg czynników. ${ }^{6}$ Wskazuje się, że jest to w pierwszym rzędzie konsekwencją dynamicznego rozwoju nauki i techniki w płaszczyźnie międzynarodowej i jednocześnie jest spójne z promowaną aktualnie polityką naukową. ${ }^{7}$ Nie bez znaczenia pozostaje bowiem fakt, że przyjmowane obecnie strategie mające na celu poprawę powiązań pomiędzy nauką a technologią poprzez wspieranie badań wymagają de facto współpracy pomiędzy sektorami uczelni i przedsiębiorstw. ${ }^{8}$ Zwraca się także uwagę na szeroko zakrojoną współpracę pomiędzy ośrodkami naukowymi w ramach prowadzonych badań naukowych, dwustronne umowy pomiędzy instytucjami oraz politykę Unii Europejskiej nakierowaną na integrację państw członkowskich. ${ }^{9}$ J.S. Katz i B.R. Martin wyróżnili szereg czynników mających wpływ na wzrost publikacji współautorskich: 1) zmiana wzorców lub poziomu finansowania, 2) dążenie do wzrostu rozpoznawalności i uznania w środowisku naukowym, 3) rosnące wymagania wobec naukowców, 4) coraz bardziej złożona aparatura, 5) znaczący wzrost specjalizacji i profesjonalizacji w zakresie nauk ścisłych, 6) postęp wiedzy wymuszający na naukowcach zdobywanie coraz to nowej wiedzy w celu dokonania znaczących odkryć, co niejednokrotnie może zostać osiągnięte wyłącznie we współpracy, 7) wzrost znaczenia badań i publikacji interdyscyplinarnych, 8) chęć korzystania z wiedzy i doświadczenia innych naukowców. ${ }^{10}$

Złożoność stanów faktycznych, w których mamy do czynienia ze współpracą naukową, stwarza szereg zagadnień wymagających rozstrzygnięcia na płaszczyźnie stosowania prawa. W szczególności należy ustalić, jaki rodzaj współpracy prowadzi do powstania współtwórczości i odróżnić te przypadki od współpracy o charakterze nietwórczym. W tym celu zasadne jest wskazanie przesłanek współtwórczości oraz dokonanie próby przełożenia rozwiązań autorskoprawnych w tym zakresie na sytuację utworów naukowych i praktyki oznaczania autorstwa i współautorstwa utworów naukowych.

W. Glänzel, A. Schubert, Double effort=Double impact? A critical view at international co-authorship in chemistry, "Scientometrics" vol. 50, nr 2 (2001), s. 199.

G. Melin, O. Persson, Studying research collaboration using co-authorships, "Scientometric" vol. 36, nr 3 (1996), s. 363. Por. M.D. Gordon, A critical reassessment of inferred relations between multiple authorship, scientific collaboration, the production of papers and their acceptance for publication, "Scientometrics" vol. 2. nr 3 (1980), s. 193.

J.S. Katz, B.R. Martin, What is research collaboration?, "Research Policy" 26 (1997), s. 1. W. Glänzel, National characteristics in international scientific co-authorship relations, "Scientometrics" vol. 51, nr 1 (2001), s. 70. J.S. Katz, B.R. Martin, What is research collaboration?.., op. cit., s. 4. 


\section{Przesłanki uznania osoby za współtwórcę utworu}

Dla przyjęcia współautorstwa utworu konieczne jest spełnienie zasadniczo trzech przesłanek, a mianowicie wkład w dzieło powinien spełniać wymogi, o których mowa w art. 1 ust. 1 ustawy z dnia 4 lutego 1994 r. o prawie autorskim i prawach pokrewnych, ${ }^{11} \mathrm{tj}$. posiadać twórczy i indywidualny charakter, wkłady twórcze powinny tworzyć jedno dzieło oraz niezbędna jest współpraca autorów, przejawiająca się co najmniej w uzgodnieniu zamiaru stworzenia wspólnego dzieła i wzajemnej akceptacji wkładów twórczych. ${ }^{12} \mathrm{~W}$ praktyce najwięcej trudności powstaje w związku z koniecznością weryfikacji pierwszej przesłanki. Niewątpliwie dla oceny wkładów o charakterze twórczym w utwór współautorski należy stosować takie same kryteria, jak w przypadku utworu pochodzącego od jednego twórcy. Jednocześnie, przy stwierdzaniu występowania w utworze współautorskim wkładu twórczego należy korzystać ze wskazówek wypracowanych przez orzecznictwo sądowe. Należy jednak zwrócić uwagę na fakt, że judykatura formułowała swe poglądy w odniesieniu do konkretnych stanów faktycznych, nie dokonując uogólnień i nie wyprowadzając precyzyjnych kryteriów. Dlatego konieczne jest każdorazowe weryfikowanie cech oryginalności i indywidualności wkładów w dzieło współautorskie oparte na okolicznościach konkretnej sprawy. ${ }^{13}$

Przedmiotowe ustalenia znajdują potwierdzenie na gruncie orzecznictwa sądowego. Należy podzielić stanowisko Sądu Najwyższego wyrażone w wyroku z dnia 19 lutego 2014 r. ${ }^{14}$ zgodnie z którym jeżeli w powstawaniu utworu uczestniczy kilka osób, status współtwórcy przysługuje tylko tym, które wniosły twórczy wkład o indywidualnym charakterze, przy czym takie same przesłanki zdolności autorskoprawnej twórczości pojedynczego twórcy obowiązują w odniesieniu do utworów będących rezultatem współtwórczości. Takiego charakteru nie ma współpraca polegająca na dokonywaniu czynności pomocniczych, nawet kwalifikowanych i wymagających własnej inicjatywy lub technicznych ściśle realizowanych według wskazówek innych osób. Trafnie zauważa dalej Sąd Najwyższy, że współtwórcy mogą uczestniczyć na różnych etapach powstawania utworu, ale muszą współdecydować o jego ostatecznym kształcie. Decydujące znaczenie ma fakt polegający na udziale w procesie powstawania utworu, a drugorzędne wartościowanie - ich wkład nie musi być równy w znaczeniu rozmiaru (wielkości), sposobu wyrażenia, charakteru i ekwiwalentnej wartości, może, ale nie musi dać się wyodrębnić i mieć samodzielne znaczenie, jednak zawsze powinien być twórczy. Słusznie zauważa dalej Sąd Najwyższy, że niezbędne jest, aby współpraca była wynikiem porozumienia, obejmującego stworzenie wspólnym wysiłkiem wspólnego dzieła przy wzajemnej

Tekst jedn. Dz.U. z 2006 r. Nr 90, poz. 631 z późn. zm., dalej cytowana jako pr. aut.

J. Barta, R. Markiewicz, Prawo autorskie, Warszawa 2013, s. 86-87.

J. Banasiuk, Współtwórczość i jej skutki w prawie autorskim, Warszawa 2012, s. 116

V CSK 180/13. 
akceptacji wkładów twórczych, przy czym nie wyklucza się jego formy konkludentnej. ${ }^{15}$ Podobnie orzekł Sąd Najwyższy w wyroku z dnia 5 lipca 2002 r., ${ }^{16}$ uznając, że współtwórczość w rozumieniu prawa autorskiego nie zachodzi, gdy współpraca określonej osoby nie ma charakteru twórczego, lecz pomocniczy, chociażby umiejętność wykonywania czynności pomocniczych wymagała wysokiego stopnia wiedzy fachowej, zręczności i inicjatywy osobistej. Współtwórczość wynikająca ze współpracy przy tworzeniu dzieła kilku osób nie może powstać niezależnie od woli twórców, musi bowiem istnieć, choćby dorozumiane, wynikające z czynności konkludentnych, porozumienie współtwórców co do stworzenia wspólnym wysiłkiem wspólnego dzieła.

\section{Współtwórczość utworów naukowych}

Kwestie autorskoprawne związane z problematyką współtwórczości utworów naukowych zostały dostrzeżone na gruncie literatury przedmiotu w drugiej połowie XX wieku. Zwraca uwagę brak jednolitego stanowiska przedstawicieli doktryny w odniesieniu do przedmiotowego zagadnienia. ${ }^{17}$ Także dziś ustalenie, jaki wkład w utwór naukowy przesądza o uznaniu osoby za współtwórcę dzieła, jest kwestią problematyczną. Należy podzielić stanowisko, zgodnie z którym współautorstwo utworu i ocena wkładów we wspólne dzieło różni się w zależności od dyscypliny naukowej - o ile w przypadku nauk społecznych samo postawienie problemu naukowego, pomoc przy sprecyzowaniu tematu czy konsultacje w tym zakresie nie są uznawane za prowadzące do powstania współtwórczości, o tyle w dziedzinie nauk eksperymentalnych specyfika prowadzonych prac wymusza poszukiwanie dodatkowych kryteriów w zakresie oceny wkładów we wspólne dzieło. ${ }^{18}$ Uwagę zwraca przytoczona przez D. Leuze dyskusja przedstawicieli doktryny dotycząca ustalenia, jaki rodzaj działalności przy współpracy nad wspólnym utworem predestynuje do miana współtwórcy, a ukazująca jednocześnie rozbieżność w ocenach przedmiotowej kwestii. Wydaje się, że zbyt daleko idące byłoby stanowisko H.G. Hauffe, zgodnie z którym asystent lekarza mógłby zobowiązać się wobec swego przełożonego do wskazania tego ostatniego jako współautora publikacji z uwagi na fakt, że przygotowywany przez niego utwór jest ,pisany w duchu kliniki”. Natomiast należałoby zasadniczo podzielić pogląd U. Loewenheima, stosownie do którego wkładem twórczym w utwór naukowy nie będzie w szczególności zebranie materiałów, przeprowadzenie badań, wykonanie preparatów anatomicznych przeznaczonych do badań, opracowanie przypisów, przygotowanie bibliografii czy korekta redakcyjna. Jed-

\footnotetext{
15 Por. wyrok Sądu Apelacyjnego w Warszawie z dnia 5 lipca 2012 r., I ACa 1076/11.

16 III CKN 1096/00, OSNC 2003/11/150.

17 D. Leuze, Die Urheberrechte der wissenschaftlicher Mitarbeiter, „Gewerblicher Rechtsschutz und Urheberrecht“ 2006, z. 7, s. 553.

18 M. Jankowska, Autor i prawo do autorstwa, Warszawa 2011, s. 473.
} 
nocześnie słuszne jest twierdzenie H. Amtmanna, że systematyczne zebranie materiałów, noszące znamiona indywidualności, może wpływać na ostateczny kształt utworu. $^{19}$

Podobnie jak na gruncie literatury przedmiotu, tak w przypadku orzecznictwa sądowego nie zostało wypracowane jednolite stanowisko w przedmiocie oceny wkładów w utwór współautorski. Sąd Najwyższy w wyroku z dnia 18 listopada 1960 r. $^{20}$ uznał, że wkładem twórczym w powstanie utworu literackiego (książki) jest opracowanie materiałów wykorzystanych następnie w pracy, dostarczenie częściowo materiału ilustracyjnego, poprawienie i przejrzenie reszty pracy, konsultacja specjalistyczna. Zwraca jednak uwagę fakt, że Sąd Najwyższy nie poświęcił więcej uwagi przedmiotowym ustaleniom, w szczególności nie precyzując, na czym polegała wskazana wyżej praca powoda. ${ }^{21}$ Podobnie w wyroku z dnia 8 września 1976 r. ${ }^{22}$ Sąd Najwyższy stwierdził, że wkładem twórczym profesora wyższej uczelni w utwór naukowy - skrypt - opracowywany wspólnie z adiunktem, mogą być notatki z wykładów, będących owocem pracy naukowej profesora. Dla stwierdzenia współautorstwa nie jest konieczne, aby obie osoby wspólnie pisały skrypt. W ocenie Sądu wystarczające jest dostarczenie wyników badań i koncepcji naukowych, udzielanie wskazówek co do treści i układu dzieła poprzez konsultacje poszczególnych fragmentów utworu i ułożenie jego konspektu czy pokrycie części kosztów związanych z przepisywaniem rękopisu. Sąd Najwyższy dla sformułowania przedmiotowej tezy uznał za niezbędne wyjaśnienie, czy powód, który sam napisał cały skrypt, wykorzystał przekazane mu przez pozwanego notatki stanowiące podstawę prowadzonych przez niego na Akademii wykładów. Sąd Najwyższy w wyroku z dnia 16 czerwca $1981 \mathrm{r}^{23}$ uznał również za wkład o charakterze twórczym sporządzenie systematyki i indeksu systematycznego będącego istotnym elementem publikacji naukowej. W wyroku z dnia 12 stycznia 1981 r. $^{24}$ Sąd Najwyższy stwierdził natomiast, że wkładem twórczym powoda był opracowanie koncepcji systemu sterowania transportem pneumatycznym. W ocenie Sądu w projekcie nie można było odróżnić elementów założeń techniczno-ekonomicznych od elementów o charakterze wyłącznie technicznym. Za wkład twórczy w utwór naukowy Sąd Najwyższy w wyroku z dnia 25 maja $2011 \mathrm{r}^{25}$ uznał weryfikację pracy naukowej polegającą na usunięciu z niej wątpliwych naukowo fragmentów. W ocenie Sądu Najwyższego na skutek interwencji powodów z pierwotnej wersji artykułu zostało usuniętych szereg jego fragmentów, w których stwierdzono, iż muzyka i muzykoterapia może być metodą leczenia bólu. Jednocze-

\footnotetext{
19 D. Leuze, Die Urheberrechte der wissenschaftlicher Mitarbeiter..., op. cit., s. 555.

20 ICR 234/60, OSN 1961, nr 4, poz. 124.

21 Por. D. Sokołowska, Kreacja przez eliminację w prawie autorskim, „Zeszyty Naukowe Uniwersytetu Jagiellońskiego. Prace z Prawa Własności Intelektualnej" 2012, z. 1, s. 7. IV CR 329/76, OSP 1978, nr 2, poz. 24. I CR 85/81, Prawo autorskie w orzecznictwie (CD-ROM), T. Grzeszak (red.), Warszawa 1998. I CR 447/80, Prawo autorskie w orzecznictwie (CD-ROM)..., op. cit. II CSK 527/10, LEX nr 794636.
} 
śnie, efekt pracy powodów nie sprowadzał się zatem do usunięcia z artykułu tezy naukowej, jak sugeruje skarżący. W wyniku zmian zaproponowanych przez powodów, niewątpliwie o charakterze merytorycznym, zmieniała się nie tylko objętość i treść artykułu opracowanego wstępnie przez pozwaną, ale także jego ogólny wydźwięk i charakter. $Z$ artykułu zostały bowiem usunięte fragmenty pozostające $\mathrm{w}$ sprzeczności z wiedzą medyczną, której pozwana nie posiadała. Miało to istotne znaczenie $\mathrm{w}$ związku z zamiarem opublikowania artykułu w czasopiśmie adresowanym do lekarzy. W przypadku utworu naukowego sposób przedstawienia problemu ma doniosłe znaczenie. Usunięcie fragmentu takiego utworu podyktowane względami merytorycznymi może mieć w kontekście powstania utworu inne znaczenie niż usunięcie np. części utworu muzycznego bądź dzieła z zakresu literatury. W konsekwencji zmian wprowadzonych przez powodów powstało zaś dzieło o innym charakterze, które bez wkładu powodów wyglądałoby inaczej. Dlatego w ocenie Sądu Najwyższego, prawidłowa była ocena Sądu Apelacyjnego, że działanie podjęte przez powodów miało charakter działalności twórczej.

Stanowisko Sądu Najwyższego budzi daleko idące wątpliwości. W tym kontekście należy podzielić pogląd M. Poźniak-Niedzielskiej i G. Tylca, zgodnie z którym czynność polegająca na ingerowaniu bądź to w strukturę utworu, bądź w jego formę czy treść merytoryczną poza współpracą na etapie ustalania ogólnej koncepcji dzieła, konstruowania planu utworu czy też podziału zadań nie uzasadnia przyznania osobie ingerującej w dzieło statusu współtwórcy. ${ }^{26}$ Tym samym ingerencja w gotowy utwór naukowy nie prowadzi do powstania współautorstwa. Przeciwny pogląd doprowadziłby do zatarcia różnic pomiędzy utworem współautorskim a opracowaniem. Cechą wyróżniającą opracowania nie jest bowiem odstęp w czasie powstawania dzieła macierzystego i zależnego, ale „brak zamiaru stworzenia wspólnego dzieła, brak porozumienia w fazie tworzenia opracowania między osobami, których twórcze wkłady zostają połączone.” Twórca opracowania dla stworzenia dzieła zależnego przy wykorzystaniu utworu macierzystego nie ma obowiązku uzyskania zgody pierwotnego twórcy - dopiero eksploatacja tak powstałego utworu wymaga porozumienia $\mathrm{z}$ autorem dzieła głównego. ${ }^{27}$

Za wkład o charakterze nietwórczym uznano wniesienie poprawek do tekstu o charakterze stylistycznym. W wyroku z dnia 7 listopada 2003 r. ${ }^{28}$ Sąd Najwyższy uznał, że wprowadzenie do utworu, będącego podręcznikiem akademickim, poprawek niemających charakteru merytorycznego, a jedynie będących poprawkami stylistycznymi czy korektorskimi, nie jest przejawem działalności twórczej i nie uzasadnia przyznania osobie, która dokonała takich poprawek, przymiotu współdóbr osobistych, „Zeszyty Naukowe Uniwersytetu Jagiellońskiego. Prace z Wynalazczości i Ochrony Własności Intelektualnej" 1992, z. 58, s. 31. 
twórcy utworu. W ocenie Sądu, ocena, czy osobom wnoszącym poprawki należy przypisać status współtwórcy, powinna być wynikiem rozważenia przede wszystkim wkładu i jego charakteru, jaki wniosły do tekstu napisanego przez powódkę osoby dokonujące poprawek tego tekstu. Podobnie uznał Sąd Najwyższy w wyroku z dnia 10 lutego 1970 r. ${ }^{29}$ W ocenie Sądu Najwyższego nie mamy do czynienia ze współautorstwem w przypadku opracowania cudzego dzieła pod kątem redakcyjnym, zaopatrzenia go w komentarze filologiczne, krytyczne, porównawcze itp. Nie ma przy tym istotnego znaczenia to, że nie miałoby racji bytu samodzielne wydanie komentarza do tekstu dzieła (tłumaczenia), przynajmniej w takiej postaci, jaką narzuca ewentualność zamieszczenia komentarza w tej samej edycji. Za współtwórcę tłumaczenia nie może być również uważana osoba, która przekład przejrzała. Problem współtwórstwa kształtuje się w sferze procesu twórczego i jego wyników w zakresie treści i formy dzieła, a nie w dziedzinie realizacji określonego programu wydawniczego, mającego w zasadzie charakter organizacyjno-techniczny.

Przenosząc powyższe ustalenia na płaszczyznę praktyki oznaczania współautorstwa utworów naukowych, należy zgodzić się z J. Bartą i R. Markiewiczem, że odbiega ona od zasad wyznaczonych przez rozwiązania autorskoprawne. Jest to podyktowane w szczególności tym, że dla oceny współtwórczości irrelewantna jest wartość utworu czy jego odkrywczy charakter, a więc te elementy, które posiadają zasadnicze znaczenie w środowisku naukowym. ${ }^{30}$ Dlatego powszechną praktyką stają się wytyczne przyjmowane zarówno w ośrodkach naukowych, jak i w poszczególnych wydawnictwach wytyczne co do „nieustawowego" ${ }^{31}$ oznaczania współautorstwa publikacji naukowych. ${ }^{32}$ Przykładowo, zgodnie z dobrymi praktykami wskazanymi (Guidelines on collaborative research and authorship) ${ }^{33} \mathrm{w}$ Uniwersytecie w Sydney, do współautorstwa upoważnia następujący wkład we wspólne dzieło: znaczny wkład w koncepcję i projekt, gromadzenia danych i/lub analizy i interpretacji danych do publikacji, a także wkład $\mathrm{w}$ opracowywanie i/lub zmiany rękopisu. Natomiast zasadniczo za wkłady predystynujące do miana współtwórcy nie są uznawane: 1) pozyskiwanie finansowania, 2) zbieranie danych, choć jakościowe zebranie danych może uzasadniać uwzględnienie autorstwa danej osoby, o ile stanowi to znaczny koncepcyjny wkład do projektu, 3) udzielanie informacji zwrotnej na temat projektu, pozbawionej konceptualizacji, analizy i interpretacji, 4) płatność za świadczone usługi jako badacz lub konsultant, 5) bycie opiekunem autora publikacji, 6) bycie kierownikiem działu, w którym zatrudnieni są autor lub autorzy. Podobne stanowisko zajmuje Międzynarodowy Komitet Wydawców Czasopism Medycznych

\footnotetext{
29 II CR 666/69, OSP 1972/2/30.

30 J. Barta, R. Markiewicz, Prawo autorskie..., op. cit., s. 90.

31 Ibidem, s. 90.

32 Por. F. Yoshikane, T. Nozawa, K.Tsuji, Comparative analysis of co-authorship networks considering authors' roles in collaboration: Differences between the theoretical and application areas, "Scientometrics" vol. 68, issue 3, s. 643 in. http://sydney.edu.au/medicine/velim/pdfs/VELIM_authorship_guidelines.pdf (data dostępu: 10.04.2015 r.).
} 
(International Committee of Medical Journal Editors), ${ }^{34}$ uznając, że status wspó1twórcy utworu naukowego powinien przysługiwać osobie, która spełnia łącznie następujące przesłanki: 1) wniosła istotny wkład do koncepcji lub projektu pracy; dokonała analizy lub interpretacji danych wykorzystanych w pracy, 2) i redagowała pracę lub przejrzała ją krytycznie pod kątem merytorycznym, 3) i ostatecznie zatwierdziła pracę do publikacji, 4) i potwierdziła, że kwestie związane z dokładnością i integralnością każdej części pracy są odpowiednio zbadane i wyjaśnione. Jednocześnie słusznie wskazuje się, że osoby nie spełniające powyższych przesłanek mogą zostać oznaczone w publikacji przykładowo jako „badacz kliniczny” lub „uczestnik badań”, a ich wkład mógłby zostać określony jako „służył jako doradca naukowy”, „dokonał krytycznego przeglądu badań”, ,uczestniczył w pisaniu lub edycji technicznej pracy". Z przedmiotowymi ustaleniami korespondują wytyczne Amerykańskiej Akademii Nauk (National Academy of Sciences of United States of America), ${ }^{35}$ zgodnie z którymi status twórcy/współtwórcy może przysługiwać wyłącznie osobie, która wniosła znaczący wkład w powstanie utworu. Natomiast osoby współpracujące $\mathrm{w}$ trakcie badań powinny zostać wskazane jako współpracownicy w przypisie dolnym oraz powinna być określona ich rola. Natomiast zgodnie ze wskazówkami kwartalnika „Postępy Psychiatrii i Neurologii” do miana współtwórstwa predystynuje: 1) zasadniczy wkład w koncepcję i projekt pracy, 2) zebranie danych i interpretacja, 3) analiza statystyczna i przygotowanie wyników badań do analizy, 4) krytyczne zrecenzowanie pod kątem istotnej zawartości intelektualnej, 5) zebranie piśmiennictwa, 6) akceptacja ostatecznej wersji do opublikowania, ${ }^{36}$ przy czym nie wskazuje się, czy przedmiotowe przesłanki powinny wystąpić łącznie.

Analiza przywołanych wyżej poglądów przedstawicieli literatury przedmiotu, orzecznictwa sądowego i dobrych praktyk przyjmowanych na uczelniach wyższych i w wydawnictwach prowadzi do wniosku, że w zakresie problematyki współtwórczości utworów naukowych mamy do czynienia z „nieustawowym” oznaczaniem współautorstwa publikacji naukowych. Wyprowadzane kryteria różnią się w zależności od dziedziny nauki i praktyk przyjmowanych w danym środowisku naukowym. Zasadniczo należy uznać, że wspólną przesłanką jest wniesienie znaczącego wkładu w powstanie publikacji naukowej. Jednakże zwraca uwagę fakt, że w większości zaleceń dla autorów nie precyzuje się, co należy rozumieć pod pojęciem „znaczący, istotny wkład”. Można zaryzykować twierdzenie, że przedmiotowa okoliczność powinna być oceniona jako słuszna, $\mathrm{z}$ uwagi na fakt, że trudno byłoby sobie wyobrazić kazuistyczne, enumeratywne wyliczenie wkładów mających istotne zna-

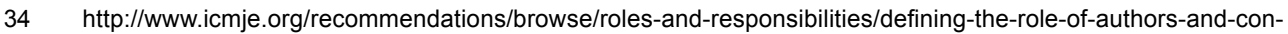
tributors.html\#two (data dostępu: 10.04.2015 r.).

35 Proceedings of the National Academy of Sciences of the USA, http://www.pnas.org/site/authors/journal.xhtml (data dostępu: 10.04.2015 r.).

36 http://www.ipin.edu.pl/ppn/reg_autorzy.php (data dostępu: 10.04.2015 r.).
} 
czenie dla powstania danej publikacji, jako że ocena charakteru współpracy może się różnić w zależności od badanej tematyki i danego obszaru wiedzy.

\section{Wnioski końcowe}

Problematyka współtwórczości utworów naukowych stanowi istotne zagadnienie zarówno z punktu widzenia rozwiązań autorskoprawnych, jak i praktyki oznaczania autorstwa utworów naukowych w działalności akademickiej. Okoliczność, że jako współtwórców prac naukowych wskazuje się nie tylko ich twórców w rozumieniu prawa autorskiego, ale także osób współuczestniczących w uzyskiwaniu wyników naukowych, należy uznać za usprawiedliwioną. ${ }^{37}$ Wydaje się, że należy podzielić stanowisko, zgodnie z którym ,nieustawowe” oznaczanie autorstwa utworów naukowych można rekonstruować w oparciu o przepis art. 23 ustawy z dnia 23 kwietnia 1964 r. - Kodeks cywilny ${ }^{38}$ i powinno spełniać łącznie trzy przesłanki, a mianowicie w środowisku naukowym powinien istnieć powszechnie akceptowany zwyczaj umieszczania jako współautorów osób opracowujących wyniki badań naukowych, niezbędny jest faktyczny udział w pracach badawczych danego podmiotu oraz przedmiotowe prace nie powinny ograniczać się do działań o charakterze mechanicznym, rutynowym czy administracyjnym, ${ }^{39}$ przy czym charakter współpracy może się różnić i powinno być to brane pod uwagę przy jego ocenie w zależności od dziedziny nauki i opracowywanego zagadnienia badawczego. Ponadto, można rozważyć, czy nie byłoby zasadne uzupełnienie przedmiotowego katalogu o wymóg akceptacji ostatecznego kształtu utworu naukowego. Na marginesie należy podnieść, że z faktem oznaczania współautorstwa publikacji naukowych wiąże się także punktacja naukowa otrzymywana przez współtwórców. O ile w dziedzinie nauk społecznych kolejność współautorów nie ma zasadniczo znaczenia dla wysokości przydzielanych punktów, o tyle w dziedzinie nauk ścisłych może to oddziaływać na wielkość przyznawanych punktów za publikację. W takiej sytuacji usprawiedliwione byłoby przyjęcie wewnętrznych, uczelnianych założeń i wskazówek dla autorów w zakresie oceny wkładu we wspólny utwór naukowy i jego wartościowania.

Wydaje się, że w przypadku utworów naukowych wkładem predystynującym do miana współautora zasadniczo nie będzie:

- samo postawienie problemu naukowego,

- pomoc przy sprecyzowaniu tematu czy konsultacje w tym zakresie,

- zebranie materiałów,

- przeprowadzenie badań,

- wykonanie preparatów anatomicznych przeznaczonych do badań, 
- opracowanie przypisów,

- przygotowanie bibliografii,

- korekta stylistyczna, redakcyjna,

- pozyskiwanie finansowania,

- udzielanie informacji zwrotnej na temat projektu, pozbawionej konceptualizacji, analizy i interpretacji,

- bycie opiekunem autora publikacji,

- bycie kierownikiem działu, w którym zatrudnieni są autor lub autorzy. 


\section{A FEW REMARKS ON CO-AUTHORSHIP OF SCIENTIFIC WORKS}

Co-authorship of scientific works is an important issue, both from the point of view of copyright rules and practices for determining scientific works by academic activity. The fact that the co-authors of scientific papers indicate not only their creators under copyright law, but also those who are complicit in obtaining scientific results, should be regarded as justified and particularly so as more and more scientific research is being conducted by separate teams working in collaboration with each other. It seems that, subject to certain conditions being met, the position should be accepted according to which "non-statutory" determination by scientific works can be reconstructed based on the provision of art. 23 of the Act of 23 April 1964 - Civil Code, The scientific community should widely accept the practice of including as co-authors those involved in developing the research.The nature and scope of collaboration may vary and this too requires to be taken into consideration. It should also be noted that determining co-authorship of scientific publications involves accruing scientific scores which may affect the size of credits for publication. Such a situation would justify universitiesadoptinginternal guidelines and tips to enable authors to assess and evaluate their contribution to a common scientific work.

Słowa kluczowe: współtwórczość, utwór naukowy, prawo autorskie

Keywords: co-authorship, scientific work, copyright law 